\title{
How Bank Managers Anticipate Non-Performing Loans Evidence from Europe, US, Asia and Africa
}

\author{
P. K. Ozili ${ }^{1}$ \\ ${ }^{1}$ Essex Business School, University of Essex. CO4 3SQ. United Kingdom. \\ Correspondence: P. K. Ozili, Essex Business School, University of Essex. CO4 3SQ. United Kingdom.
}

Received: April 11, 2015

Accepted: April 15, 2015

Available online: June 12, 2015

doi:10.11114/afa.v1i2.880

URL: http://dx.doi.org/10.11114/afa.v1i2.880

\begin{abstract}
This study extends the literature on the determinants of NPL. I investigate whether banks anticipate non-performing loans by making balance sheet adjustments. This study draws insight into the actions taken by credit risk management teams and bank managers to minimize the size of non-performing loans. After examining 82 banks from US, Europe, Asia and Africa, the result indicate that banks adjust the level of loan loss reserves and loan growth to minimize the size of NPLs. Our results do not show evidence that loan diversification minimizes NPLs. Further, I find that banks in developing countries reduce loan growth when they expect high NPL while banks in developed countries do not anticipate the level of NPL by adjusting loan growth. Further, I find that post-crisis Basel regulation did not lead to a decrease in the size of NPLs among banks in developed countries but appear to minimize NPLs in some developing countries. Overall, the significance and predictive power of each bank-specific factor (excluding loan diversification), regulatory variable and macroeconomic indicator in explaining NPLs depends on regional factors (less significantly) and country-specific factors (more significantly).
\end{abstract}

Keywords: Non-performing Loans, Credit risk, Macroeconomic determinants, Bank specific determinants, Banking.

\section{Introduction}

The deterioration in the quality of bank assets continues to take centre stage in banking research and policy discuss since the 2008 financial crisis. The need to predict early warning signals of NPLs is increasingly becoming important to bank managers and credit controllers. Prior studies identified several determinants of NPLs, for example, cost efficiency, bad management, bad luck, institutional factors, moral hazard and macroeconomic factors (e.g. Berger and DeYoung, 1997; Carey, 1998; Salas and Saurina, 2002; Louzis et al. 2011). However, there is a need to proceed from prior studies to investigate how banks anticipate NPLs, particularly, by making some balance sheet adjustments. Because NPLs cannot be accurately predicted due to adverse selection and moral hazard issues, managers take certain proactive steps or actions to minimize credit losses arising from problem loan. Therefore, this paper goes beyond the literature on NPL determinants to examine how managers anticipate NPLs.

The main objective of this paper is to identify bank-specific variables that bank managers are likely to influence in anticipation of non-performing loans to minimize the size of NPLs. To address this question, we employ single-equation panel OLS regression. Second, I address the question on the interaction between NPLs and the state of the business cycle. Third, I note that distinctive characteristics of each country's banking industry and economic system are expected to have an effect on the size of NPLs. Therefore, in our robustness check, I undertake some country-specific analysis to observe whether country-specific differences show any significant results. Fourth, I propose that bank-specific determinants of NPLs may change as regulatory regimes change. Thus, I examine whether strict banking regulation in the post-crisis era translates into sound credit risk management leading to lower NPLs.

The paper contributes to an extensive body of literature, both theoretical and empirical, on the interactions between NPL and macroeconomic conditions (e.g. Keeton and Morris, 1985; Rinaldi and Sanchis-Arellano, 2006; Quagliariello, 2007; Jappelli, Pagano, and Marco, 2008; Espinosa and Prasad, 2010). To the best of my knowledge, this paper is the first to combine regional bank samples and country-specific bank samples. I note that undertaking regional analysis does not capture country-specific factors; however, I maintain that banks tend to adopt some common 'best practices' in credit risk management regardless of the region of the bank. Also, this paper is unique in that, unlike prior studies, we employ a different bank size variable, gross loan, as a proxy for bank diversification opportunities. The rationale for this 
follows the view that NPL should have a direct impact on gross loan relative to total asset. Our findings in this paper indicate that bank managers anticipate NPLs by making balance sheet adjustments as a credit risk management practice. The results confirm that NPL has macro-financial linkage with the state of the business cycle in some countries. Also, our findings show evidence that bank loan portfolio may not be well-diversified.

The paper is organized as follows. Section II reviews the literature and develops the hypothesis for empirical testing. Section III presents the econometric methodology. Section IV reports and discusses the econometric results. Section V concludes and discusses the policy implications of our findings.

\section{Literature Review and Hypothesis Development}

\subsection{NPLs and Loan Growth}

Clark (1992) examined the relation between loan growth and loan quality. Following Clark (1992)'s theoretical framework, banks seeking to increase its overall market share might lower its underwriting standards to attract more loan customers. To attract new customers, banks might lower the non-price terms of the loan. Also, even if a bank maintains the same credit standards, it might possibly attract borrowers of lower loan quality, thus, increasing the risk exposure on the loan exposure. However, Anandarajan et al (2007) argue that the risk on bank loan portfolio depends on the quality of incremental loans. Therefore, the relationship between NPL and loan growth is likely to depend on the quality of incremental loans. Nonetheless, the quality of incremental loan or loan growth is often unobservable, thus, it is difficult to predict the relationship between NPL and loan growth.

From a credit risk management perspective, when banks anticipate NPLs, bank managers would decrease lending in the current period to minimize expected credit loss. Thus, we expect a negative relationship between NPL and loan growth.

\subsection{NPL and Diversification Opportunities}

The literature suggests that banks' diversification opportunities may be related to loan quality (e.g. Salas and Saurina, 2002; Hu et al. 2004; and Rajan and Dhal, 2003). These studies employed bank size (total asset) as a proxy for diversification. For example, Salas and Saurina (2002) find a significant negative relation between bank size and NPLs. They argue that large banks tend to be more diversified and that diversification reduces credit risk. Alternative measures of diversification have been employed. For example, Louzis et al (2011) employed total asset and non-interest income and did not find evidence to support the bank size diversification hypothesis. They concluded that bank size, proxy by total asset, does not fully capture diversification. Additionally, Louzis et al (2011) employed non-interest income as an alternative proxy for diversification effect, but did not find a significant negative relation between NPLs and diversification. Overall, empirical evidence for diversification effects on LLP appears mixed. In the present study, I consider using an alternative diversification proxy - size of gross loan, to observe whether there is any significant diversification effect. Bank size, proxied by size of gross loan, is expected to have a negative relationship with NPLs. This follows the reasoning that banks are expected to maintain a well-diversified loan portfolio. A diversified portfolio spreads credit risk across heterogeneous and unrelated debtors. This sharing of risk reduces the size of NPL relative to a non-diversified loan portfolio.

\subsection{NPLs and Macroeconomic Determinants}

The theoretical literature argue that the state of the economy is an most important factor influencing loss rates on diversified loan portfolios (e.g. Carey, 1998; Ruckes, 2004; Geanakoplos, 2010). The literature argue that in good economic times, banks tend to extend credit to low quality debtors but when a recession sets in, NPLs are expected to increase. Empirical studies appear to show consistent evidence for this macro-financial linkage (e.g. Quagliarello, 2007; Klein, 2013). For example, Quagliarello (2007) in a study of Italian banks from 1985-2002, found that the state of the business cycle is a determinant of NPLs. Klein (2013) examines NPLs in Central, Eastern and South- Eastern Europe (CESEE) countries to determine whether NPL is driven by macroeconomic factors. Klein (2013) examined the relationship between NPL and macroeconomic factors such as change in gross domestic factors, unemployment, and inflation. Klein (2013) found a strong negative relationship between NPL and the state of the business cycle proxy by change in gross domestic product. Other studies include: Keeton and Morris (1985), Rinaldi and Sanchis-Arellano (2006), Salas and Saurina (2002), Carey (2002), Pagano, and Marco (2008), Boss et al. (2009), and Espinosa and Prasad (2010). Therefore, consistent with prior studies, we expect a negative relationship between NPL and the state of the business cycle, proxied by change in gross domestic product. A negative sign indicates NPL is procyclical with the state of the business cycle. A positive sign would indicate counter-cyclical NPL behaviour.

\subsection{NPL and Loan Loss Reserves}

When banks expect NPLs, banks will increase loan loss provisions. Increase in provisions translates into increase in loan loss reserves. Thus, a positive relationship between NPL and reserves is expected. 


\section{Methodology}

\subsection{Data and Sample Selection}

Data used in this study were obtained from Thomson's (Bureau van Dijk) Bankscope Database. Annual bank data from the period 2004 to 2013 were extracted. Only banks with reporting data from 2004 to 2013 are included in the sample. A justification for this choice sample period is to capture significant economic downturns and upturns as well as the 2007-2008 financial crisis. To obtain large bank samples, I do not make any distinction between commercial banks and non-commercial banks. In all, the final sample is reduced to 82 banks which yield 820 bank-year observations. Surprisingly, I observe that some banks did not report NPL data for some years. Also, I note that the introduction of lagged variables in the model adjusts the beginning sample period from 2004 to 2005 . After the adjustment, the final sample yields 679 bank-year observations.

\subsection{Model Specification}

The basic estimation strategy is to pool the observations across banks and undertake regression analysis on country-specific pooled sample. Pooling has the advantage of generating more reliable estimates in the model. However, the validity of pooled panel analysis depends on whether there is a reason to believe that the relationship between the variables is stable across cross-section units. While this assumption is unlikely to hold, pooling the data over time and across banks significantly increases the degrees of freedom.

Given that banks in the same country face common economic shocks, panel least square is more appropriate to examine the behaviour of NPL for country-specific banking industry. The disadvantage of pooled panel is that heterogeneity across banks often reveals itself in the "unexplained" residuals or error term. Also, unlike studies that introduce country specific dummy variables into the model, I adopt country-specific regression model in order to allow country-specific peculiarities to be incorporated into the model. This follows the reasoning that country-specific factors have some impact on non-performing loans.

Therefore, I adopt a modified model derived from existing NPL models in the literature (e.g. Louzis et al. 2011). The baseline model captures bank-specific variables and macroeconomic variables. To capture bank-specific heterogeneity, I use panel OLS with fixed effects. The econometric model is,

$$
\mathrm{NPLit}=\mathrm{LLR}_{i t}+\mathrm{LOTA}_{i t}+\mathrm{LOAN}_{i t}+\mathrm{InGLit}_{+} \mathrm{GDP}_{\mathrm{t}}+\varepsilon i t
$$

Where,

$\mathrm{NPL}=$ Non-performing loans for bank $\mathrm{i}$ at time $\mathrm{t}$

LOTA $=$ total loan to total asset for bank $\mathrm{i}$ at time $\mathrm{t}$

LOAN $=$ growth in gross loan for bank $\mathrm{i}$ at time $\mathrm{t}$

$\mathrm{InGL}=$ size of gross loan as a proxy for loan portfolio size for bank $\mathrm{i}$ at time $\mathrm{t}$.

GDP = change in gross domestic product for country at time t. A proxy for state of the business cycle.

$\mathrm{GDP}_{\mathrm{t}-1}=$ the previous state of the business cycle.

The dependent variable is aggregate NPL. NPL is ratio of impaired loans to gross loan. The variables of interest are LLR, LOAN, InGL, LOTA, and GDP. LLR is the ratio of loan loss reserves to gross loans. LOAN is the change in gross loan. LOTA is the ratio of gross loan to asset. InGL is the natural logarithm of gross loan. GDP is the gross domestic product growth rate. These variables explain factors, within managerial control, that might help banks to predict or control the overall size of NPL to some considerable extent.

I control for the riskiness of banks' asset composition by employing gross loan to asset variable (LOTA). We expect that banks with large loan assets relative to non-loan assets have greater exposure to credit losses than less risky banks. A significant positive sign on the LOTA variable would indicate that risky banks tend to have greater NPLs. On the other hand, if a negative sign on the LOTA variable is observed, it would indicate that loan assets of risky banks appear to be well-diversified, hence, low NPLs.

Also, a positive sign is expected on LOAN variable. It follows the reasoning that increases in loan size is often associated with declining banks loan quality and, thus, increased NPLs. GDP and GDPt-1 tests whether NPL is 
procyclical with the business cycle. This is consistent with prior studies (e.g. Salas and Saurina, 2002; Louzis et al, 2011; Klien, 2013). A negative sign indicates that NPL is procyclical with the business cycle, otherwise, positive. Finally, a negative relationship is expected between the InGL variable and NPL.

\section{Discussion of Results}

\subsection{Descriptive statistics}

Table 1 presents the descriptive statistics for the period 2004-2013 for our sample banks. The mean ratio of LLR to gross loan for the full bank sample are $2.58 \%$. With regard to the credit quality of banks in our sample, non-performing loans (NPL) are, on average, $4.03 \%$ of gross loan. On average, growth in loan (LOAN) is $14.28 \%$. With regard to the size of bank loan portfolio, the natural logarithm of gross loan (InGL) is $17.45 \%$ indicating a fairly stable loan portfolio. On average, the riskiness of banks total asset portfolio (LOTA) is 51.86 indicating that banks appear to be risky in their lending activities. On average, GDP is $4.02 \%$.

Table 1. Descriptive Statistics

\begin{tabular}{cccccccccccc}
\hline & Total & \multicolumn{4}{c}{ Region } & \multicolumn{5}{c}{ Some Countries } \\
\hline Var. & Statistic & All banks & Europe & US & Asia & Africa & UK & China & India & Indonesia & S/Africa \\
LLR & Mean & 2.58 & 2.34 & 2.18 & 2.55 & 3.09 & 2.13 & 2.54 & 1.75 & 3.86 & 1.72 \\
& Median & 2.04 & 2.20 & 1.91 & 1.98 & 2.09 & 1.59 & 2.30 & 1.51 & 2.80 & 1.75 \\
& S.D & 2.34 & 1.42 & 1.32 & 2.09 & 3.46 & 1.56 & 1.67 & 1.27 & 2.76 & 0.69 \\
NPL & Mean & 4.03 & 4.34 & 3.09 & 2.95 & 5.95 & 4.59 & 1.83 & 3.05 & 4.09 & 3.67 \\
& Median & 2.88 & 3.74 & 2.40 & 2.32 & 3.97 & 3.41 & 1.12 & 2.99 & 3.16 & 3.58 \\
& S.D & 4.42 & 2.76 & 3.27 & 3.13 & 6.63 & 3.32 & 2.49 & 1.44 & 3.51 & 1.98 \\
LOAN & Mean & 14.28 & 6.25 & 9.16 & 19.27 & 17.57 & 6.46 & 20.84 & 21.49 & 27.62 & 11.92 \\
& Median & 11.74 & 2.24 & 20.18 & 16.86 & 15.99 & 2.35 & 16.41 & 20.53 & 24.31 & 12.01 \\
& S.D & 20.06 & 21.10 & 20.17 & 19.69 & 16.30 & 25.93 & 18.57 & 12.36 & 22.42 & 11.07 \\
InGL & Mean & 17.45 & 19.05 & 19.83 & 17.51 & 14.53 & 19.47 & 19.52 & 16.56 & 14.82 & 17.61 \\
& Median & 18.00 & 20.03 & 20.17 & 17.56 & 14.17 & 20.34 & 19.55 & 16.51 & 14.96 & 17.82 \\
& S.D & 3.16 & 2.31 & 0.94 & 2.54 & 3.24 & 1.86 & 0.99 & 0.72 & 1.99 & 0.58 \\
LOTA & Mean & 51.89 & 44.76 & 43.11 & 55.20 & 57.21 & 41.87 & 54.20 & 55.35 & 61.53 & 61.67 \\
& Median & 52.50 & 41.55 & 43.86 & 54.61 & 56.26 & 38.78 & 52.32 & 58.55 & 63.15 & 66.29 \\
& S.D & 15.91 & 15.48 & 19.17 & 13.81 & 12.75 & 12.45 & 14.15 & 8.21 & 11.42 & 13.61 \\
GDP & Mean & 4.02 & 1.09 & 1.70 & 6.28 & 4.66 & 1.29 & 10.04 & 7.54 & 5.82 & 3.31 \\
& Median & 4.00 & 2.00 & 2.00 & 6.00 & 5.50 & 2.00 & 10.00 & 8.00 & 6.00 & 4.00 \\
& S.D & 3.69 & 2.29 & 1.89 & 3.73 & 2.68 & 2.11 & 1.89 & 2.07 & 0.39 & 2.38 \\
Obsv & & 749 & 170 & 105 & 283 & 190 & 80 & 77 & 59 & 87 & 89 \\
\hline
\end{tabular}

4.2 Determinants of NPL

Table 2 and 3 reports the determinants of NPLs. LLR is significant across all bank samples in Table 2 and 3. The implication is that reserves are likely to increase when banks anticipate increasing NPLs. Loan growth (LOAN) is negative and statistically significant for the full bank sample (Table 2a). Also, loan growth (LOAN) is significant and negative for US and African banks (Table 2b). This indicates that change in gross loan are, particularly, sensitive to credit risk considerations and that some regional banks tend to decrease growth in loan when they expect high NPLs. However, loan growth coefficient is statistically insignificant for European and Asian banks.

Table 2: Determinants of NPL

\begin{tabular}{|c|c|c|c|c|c|c|}
\hline & & \multirow{2}{*}{$\begin{array}{c}2 \mathrm{a} \\
\text { All banks }\end{array}$} & \multicolumn{4}{|c|}{$2 \mathrm{~b}$ (Regional banks) } \\
\hline & & & US & Europe & Africa & Asia \\
\hline Variables & Exp./ & Coefficient & Coefficient & Coefficient & Coefficient & Coefficient \\
\hline \multirow[t]{2}{*}{$\mathrm{C}$} & $?$ & 1.955 & -3.116 & $-3.376^{*}$ & 2.232 & 0.835 \\
\hline & & 1.13 & -0.36 & -1.88 & 0.48 & 0.28 \\
\hline \multirow[t]{2}{*}{ LLR } & + & $1.307^{* * * *}$ & $1.092 * * *$ & $1.723 * * *$ & $1.47^{* * *}$ & $1.046^{* * *}$ \\
\hline & & 23.97 & 6.74 & 17.98 & 11.15 & 11.39 \\
\hline
\end{tabular}




\begin{tabular}{ccccccc}
\hline LOAN & - & $-0.019^{* * *}$ & $-0.016^{* *}$ & -0.007 & $-0.073^{* * *}$ & -0.012 \\
& & -3.68 & -2.29 & -1.36 & -2.95 & -1.44 \\
InGL & - & 0.021 & 0.49 & $0.164^{* *}$ & -0.276 & -0.094 \\
& & 0.22 & 1.02 & 1.95 & -0.98 & -0.64 \\
LOTA & $+/-$ & $-0.021^{*}$ & $-0.139^{* * *}$ & 0.01 & $0.108^{*}$ & $0.025^{*}$ \\
& & -1.67 & -6.87 & 0.76 & 1.86 & 1.71 \\
GDP & - & $-0.074^{*}$ & $0.163^{* *}$ & -0.066 & -0.243 & -0.176 \\
& & -1.82 & 2.03 & -1.53 & -1.37 & -1.16 \\
Adj R & & 74.42 & 83.16 & 80.69 & 80.21 & 4.03 \\
F-stat & & $26.31^{* * *}$ & $35.25 * * *$ & $30.44^{* * *}$ & $28.03^{* * *}$ & $9.64^{* * *}$ \\
Obsv. & 749 & 105 & 170 & 101 & 293 \\
\hline
\end{tabular}

Table 3 reports a negative and significant sign on the LOAN variable for all countries except Uganda and Indonesia. Moreover, I did not find any significant diversification effect influencing NPL for regional bank as indicated by the InGL variable. However, we find significant diversification effect for only Chinese banks in Table 3. LOTA coefficient appears to be negative and weakly significant for the full bank sample indicating that increased loan-to-asset ratio minimizes NPL. A possible explanation for this negative relationship is due to the fact that the loan component of total assets appears to be well diversified. Interestingly, LOTA coefficient is negative and strongly significant for US banks but is positive and weakly significant for Asian and African banks. The positive sign indicates that risky banks are likely to have higher NPLs. Also, we find that NPL is procyclical with the business cycle in the full sample as indicated by the GPR variable. However, the GDPR coefficient is positive for US banks indicating counter-cyclical NPL behaviour among US banks. This result is mostly insignificant for Asian, African and European banks except for Indian banks in Table 3. Overall, the result suggests that bank NPLs behaviour may be driven by regional banking differences.

Table 3. Country-Specific Determinants

\begin{tabular}{|c|c|c|c|c|c|c|c|c|c|}
\hline & & UK & China & India & S/Africa & Uganda & Kenya & France & Indonesia \\
\hline Variables & Exp./ & Coefficient & Coefficient & Coefficient & Coefficient & Coefficient & Coefficient & Coefficient & Coefficient \\
\hline \multirow[t]{2}{*}{$\mathrm{C}$} & $?$ & $-56.04 * * *$ & $16.81 * * *$ & $9.649 * *$ & $-54.322 * * *$ & 13.48 & $-19.67 * * *$ & -4.839 & $-9.633^{*}$ \\
\hline & & -4.89 & 3.85 & 1.99 & -4.27 & 0.99 & -2.82 & -0.75 & -1.67 \\
\hline \multirow[t]{2}{*}{ LLR } & + & $1.764 * * *$ & $1.25 * * *$ & $0.928 * * *$ & $1.943 * * *$ & $0.0001 * * *$ & $1.651 * * *$ & $1.509 * * *$ & $1.043 * * *$ \\
\hline & & 13.65 & 23.61 & 9.55 & 6.04 & 4.46 & 11.65 & 9.47 & 5.94 \\
\hline \multirow[t]{2}{*}{ LOAN } & - & $-0.016^{* *}$ & $-0.015^{* *}$ & $-0.027 * *$ & $-0.039 * *$ & -0.005 & $-0.089 * * *$ & $-0.021 *$ & -0.011 \\
\hline & & -2.38 & -2.43 & -2.45 & -2.59 & -0.17 & -2.90 & -1.94 & -0.97 \\
\hline INGL & & 4.87 & -5.57 & -1.57 & 4.28 & -0.41 & -0.79 & 1.09 & 1.33 \\
\hline \multirow[t]{2}{*}{ LOTA } & $+/-$ & 0.005 & -0.026 & 0.021 & 0.006 & -0.055 & $0.472 * * *$ & $-0.058 * * *$ & -0.007 \\
\hline & & 0.18 & -1.45 & 0.83 & 0.49 & -0.73 & 4.81 & -3.14 & -0.15 \\
\hline \multirow[t]{2}{*}{ GDP } & - & -0.043 & 0.026 & $-0.114 * *$ & 0.051 & -1.955 & -0.049 & -0.047 & $1.084 *$ \\
\hline & & -0.56 & 0.42 & -2.40 & -0.96 & -1.07 & -0.24 & -0.98 & 1.76 \\
\hline Adj $R^{2}$ & & 83.97 & 92.77 & 77.32 & 82.15 & 75.65 & 83.19 & 90.92 & 64.49 \\
\hline F-stat & & $33.23 * * *$ & $76.09 * * *$ & $20.78 * * *$ & $29.93 * * *$ & $15.76^{* * * *}$ & $28.01 * * *$ & $41.03 * * *$ & $13.01 * * *$ \\
\hline Obsv. & & 81 & 77 & 59 & 89 & 39 & 61 & 37 & 87 \\
\hline
\end{tabular}


The reported adjusted $\mathrm{R}^{2}$ in Table 2 and Table 3 is above $70 \%$ and $60 \%$, respectively. The F-statistics shows that the variables jointly explains NPLs and are significant at the $1 \%$ significance level.

\subsection{Further robust Test}

\subsubsection{NPL and Country-specific Influences}

Prior studies argue that the behaviour of NPLs may be driven by the uniqueness of a country's banking industry (Louzis et al 2011). Therefore, I analyse country-specific NPL behaviour. The advantage of country specific analysis is that it captures the peculiarities of a country's banking industry, institutional characteristics and relevant macroeconomic characteristics as well. Interestingly, table 4 reports a positive and strongly significant coefficient on the LLR variable at the $1 \%$ significant level. This is consistent with Ozili (2015). Also, the result reports that LOAN is negative and statistically significant for banks in China, India, South Africa, Kenya and Indonesia but is insignificant for U.S and European banks (e.g. UK, France and Germany). This result indicates that banks in developing countries adjust the size of gross loan to minimize their risk exposure. The result is not significant result for US and UK banks. This suggests that banks in developed countries do not appear to anticipate the level of NPL by adjusting the size of gross loan. An explanation for this might be that banks in developed countries rely on alternative credit risk management mechanisms to anticipate the size of NPLs. Similarly, LOTA is negative and significant for US banks but is positive and significant for banks in India and Kenya. Also, InGL is negative and significant for Chinese banks but is positive and significant for banks in UK and South African banks. This result provides weak support for the hypothesis on diversification effect.

Table 4. Robustness Check (Lagged variable and REG)

\begin{tabular}{|c|c|c|c|c|c|c|c|c|c|c|c|c|c|c|}
\hline \multirow[t]{3}{*}{ Model } & \multicolumn{14}{|c|}{ NPL=LLR + LOAN + INGL + LOTA + REG + GDP + GDP(-1) } \\
\hline & Full & US & Europe & Asia & Africa & Germany & UK & China & India & S/Africa & Uganda & Kenya & France & Indonesia \\
\hline & Sample & & & & & & & & & & & & & \\
\hline \multirow[t]{2}{*}{ Var } & Coeff & Coeff & Coeff & Coeff & Coeff & Coeff & Coeff & Coeff & Coeff & Coeff & Coeff & Coeff & Coeff & Coeff \\
\hline & (t-stat) & (t-stat) & (t-stat) & (t-stat) & (t-stat) & (t-stat) & (t-stat) & (t-stat) & (t-stat) & (t-stat) & (t-stat) & (t-stat) & (t-stat) & (t-stat) \\
\hline \multirow[t]{2}{*}{ C } & $3.24 *$ & 14.80 & $-4.208^{* * *}$ & 2.89 & 3.663 & -1.195 & $-36.57 * * *$ & $25.35 * * *$ & 5.226 & $-67.08^{* * * *}$ & 31.99 & $-17.19^{* * * *}$ & -1.994 & 3.113 \\
\hline & 1.77 & 1.29 & -2.49 & 0.831 & 0.67 & -0.48 & -3.45 & 4.56 & 0.62 & -4.54 & 1.44 & -2.54 & -0.27 & 0.39 \\
\hline \multirow[t]{2}{*}{ LLR } & $1.299^{* * * *}$ & $0.919^{* * *}$ & $1.505^{* * * *}$ & $0.911^{* * * *}$ & $1.388^{* * * *}$ & $1.737^{* * * *}$ & $1.379 * * *$ & $0.457 * * *$ & $0.85^{\text {**** }}$ & $2.033^{* * * *}$ & $1.498^{* * * *}$ & $1.449 * * *$ & $1.387^{* * * *}$ & $1.009^{* * * *}$ \\
\hline & 21.06 & 4.12 & 15.01 & 7.00 & 9.31 & 7.37 & 10.41 & 2.83 & 7.07 & 6.29 & 3.74 & 8.94 & 7.31 & 5.11 \\
\hline \multirow[t]{2}{*}{ LOAN } & $-0.019^{* * * *}$ & -0.007 & -0.003 & -0.014 & $-0.077 * * *$ & -0.007 & -0.006 & $-0.018^{* * * *}$ & $-0.043^{* * * *}$ & $-0.041^{* * * *}$ & -0.011 & $-0.101 * * *$ & -0.021 & $-0.025^{*}$ \\
\hline & -3.43 & -0.82 & -0.58 & -1.35 & -2.88 & -0.79 & -0.93 & -2.83 & -3.42 & -2.70 & -0.33 & -3.27 & -1.62 & -1.65 \\
\hline \multirow[t]{2}{*}{ INGL } & $0.001^{* *}$ & -0.499 & $0.163^{* *}$ & -0.177 & -0.251 & 0.093 & $1.842^{* * * *}$ & $-1.073^{* * * *}$ & -0.368 & $3.928^{* * * *}$ & -1.933 & -0.094 & 0.252 & $0.604 * * *$ \\
\hline & 0.015 & -0.79 & 2.16 & -1.09 & -0.83 & 1.35 & 3.25 & -3.79 & -0.65 & 4.62 & -1.04 & -0.34 & 0.68 & 2.59 \\
\hline \multirow[t]{2}{*}{ LOTA } & $-0.029^{* *}$ & $-0.109^{* * * * *}$ & $0.032^{*}$ & 0.019 & $0.13^{* *}$ & -0.011 & 0.037 & -0.028 & $0.07^{* * *}$ & -0.001 & -0.057 & $0.483^{* * * *}$ & $-0.069^{* * * * *}$ & -0.003 \\
\hline & -2.15 & -4.41 & 1.69 & 1.17 & 1.95 & -0.27 & 1.37 & -1.62 & 2.24 & -0.098 & -0.73 & 5.09 & -3.17 & -0.06 \\
\hline \multirow[t]{2}{*}{ REG } & -0.131 & $1.313^{* * *}$ & $1.043^{* * * *}$ & -0.052 & -0.961 & 0.344 & $1.89 * * *$ & -0.566 & -0.084 & $-1.059^{* * * *}$ & 0.358 & $-2.596^{* * *}$ & 0.069 & -0.983 \\
\hline & -0.60 & 2.69 & 4.16 & -0.176 & -1.53 & 1.00 & 3.82 & -1.43 & -0.23 & -2.57 & 0.15 & -2.13 & 0.34 & -1.53 \\
\hline \multirow[t]{2}{*}{ GDP } & $-0.077^{*}$ & $0.157^{*}$ & -0.016 & -0.012 & -0.276 & 0.004 & 0.033 & -0.003 & -0.069 & $-0.149^{* * *}$ & -0.491 & 0.023 & -0.049 & -0.169 \\
\hline & -1.81 & 1.88 & -0.40 & -0.16 & -1.53 & 0.088 & 0.49 & -0.05 & -1.56 & -2.29 & -0.99 & 0.11 & -0.93 & -0.19 \\
\hline \multirow[t]{2}{*}{ GDP(-1) } & $-0.088^{*}$ & 0.068 & -0.05 & 0.015 & -0.287 & 0.004 & -0.081 & $-0.158^{* * *}$ & -0.011 & -0.081 & -0.319 & $-0.433^{*}$ & $-0.098^{*}$ & -1.623 \\
\hline & -1.91 & 0.704 & -1.19 & 0.19 & -1.41 & 0.085 & -1.03 & -2.55 & -0.19 & -1.39 & -0.83 & -1.83 & -1.81 & -0.19 \\
\hline Adj $R^{2}$ & 74.98 & 84.36 & 84.88 & 38.07 & 80.72 & 84.09 & 88.49 & 81.72 & 72.05 & 83.2 & 76.06 & 85.66 & 90.76 & 69.31 \\
\hline F-stat & $24.80^{* * * *}$ & $31.78^{* * * *}$ & $35.98^{* * * *}$ & $6.13^{* * *}$ & $23.90^{* * * *}$ & $21.71^{* * * *}$ & $40.46^{* * * *}$ & $21.86^{* * * *}$ & $12.17^{* * * *}$ & $28.24 * * * *$ & $11.81^{* * * * *}$ & $27.19^{\text {***** }}$ & $29.56^{* * * *}$ & $12.59^{* * * *}$ \\
\hline Obsv. & 700 & 98 & 163 & 268 & 94 & 48 & 78 & 71 & 53 & 89 & 35 & 58 & 33 & 78 \\
\hline
\end{tabular}

4.3.2 NPL and Regulation

I introduce a regulatory dummy to indicate strict post-2008 strict banking regulation. I investigate whether strict banking regulation leads to sound credit risk management and translates to lower NPLs for bank. Therefore, a negative relationship is expected.

$$
\text { NPLit = LLRit + LOTAit + LOANit + InGLit + REG + GDPt +GDPt }-1+\varepsilon i t
$$


The results are reported in table 4. Introducing the REG variable into the model improves the overall explanatory power of the model. A negative and insignificant sign on the REG coefficient is reported for the full sample. REG coefficient is negative and significant for banks in South Africa and Kenya but insignificant for Asian banks (China, India and Indonesia). On the other hand, REG coefficient is positive and significant for banks in US, Europe and UK. This result provides some interesting findings.

First, the result seem to suggest that post-2008 banking regulation in developed countries was not necessarily aimed at reducing NPLs, particularly, because bank regulators believe that minimizing NPLs is the responsibility of banks not regulators. This explanation may be supported by the fact that banking regulation in developed counties (such as the US and UK) after the 2008 crisis was aimed at regulating bank derivatives and securitization activities not bank loan portfolio.

\subsubsection{NPL and lagged business cycle effects}

I examine the inclusion of a lagged macroeconomic variable, particularly, one-year lagged GDPR variable.

$$
\text { NPLit }=\text { LLR + LOTAit + LOANit + InGLit + GDPt + GDPt-1 + } i t
$$

The result is reported in Table 4 above. The inclusion of lagged GDPR improves the explanatory power of the model. The lagged GDPR coefficient reports evidence of procyclical NPL behaviour for the full bank sample. This implies that there are cyclical interactions and macro-financial inter-linkages between NPL and the state of the economy. The result also reports procyclical NPL behaviour for banks in China, Kenya and France.

\section{Conclusion and Future Direction}

In this study, we use panel regression methods to examine bank specific factors to anticipate NPLs. I find that bank-specific variables such as loan loss reserves, loan growth and loan to asset ratio and state of the economy are important determinants of NPLs and possess significant explanatory power when incorporated into the baseline model. Also, we find some evidence for procyclical NPL behaviour suggesting that there are cyclical interactions and macro-financial inter-linkages between NPL and the state of the economy. Further, regulation does not appear to have a predictable relationship NPLs. I provide an explanation for this. Also, we can rely on future research to provide alternative explanation for this.

Overall, we conclude that the significance and predictive power of each bank specific factor, regulatory variable and macroeconomic indicator in explaining NPLs depends on regional factors (less significantly) and country-specific factors (more significantly). The findings in this paper have implications for policy. Regulatory authorities should ensure that banks have robust risk management systems and that such system should be directed at minimizing NPLs. The need for regulators to curb risk-taking behaviour on derivatives and securitization-related activities should not undermine the need to mitigate credit risk exposure on banks' overall loan portfolio to ensure bank stability. Future study can examine country-specific determinants of NPLs with the aim to understand how country-specific peculiarities affect NPLs. Also, further study may replicate this study and employ other proxies for loan diversification rather than total loan as a proxy for diversification.

\section{References}

Anandarajan, A., Hasan, I., \& McCarthy, C. (2007). Use of Loan Loss Provisions for Capital, Earnings Management and Signalling by Australian Banks. Accounting and Finance, 47(3), 357-379.

Berger, A., \& De-Young, R. (1997). Problem Loans and Cost Efficiency in Commercial Banks. Journal of Banking and Finance, 21, 849-870.

Boss, M., Fenz, G., Pann, J., Puhr, C., Schneider, M., \& Ubl, E. (2009). Modeling credit risk through the Austrian business cycle: An update of the OeNb model. Financial Stability Report, 17, 85-101.

Carey, M. (1998). Credit risk in private debt portfolios. Journal of Finance, 53, 1363-1387.

Clair, R. T. (1992). Loan growth and loan quality: some preliminary evidence from Texas banks. Economic Review, Federal Reserve Bank of Dallas, Third Quarter, 9-22.

Espinoza, R., Prasad, A. (2010), Nonperforming Loans in the GCC Banking Systems and their Macroeconomic Effects, 
IMF Working Paper 10/224 (Washington: International Monetary Fund).

Geanakoplos, J. (2010). The leverage cycle. In NBER Macroeconomics Annual, 24, 1-65. University of Chicago Press.

Hu, J. L., Li, Y., Chiu, Y. H. (2004), Ownership and nonperforming loans: Evidence from Taiwan's banks. The Developing Economies, 42(3), 405-420.

Jappelli, T., Pagano, M., \& Di-Maggio, M. (2013). Households' indebtedness and financial fragility. Journal of Financial Management, Markets and Institutions, 1(1), 26-35.

Keeton, W. R., \& Morris, C. S. (1987). Why Do Banks7 Loan Losses Differ? Economic Review, 3-21.

Klein, N. (2013). Non-performing loans in CESEE: Determinants and impact on macroeconomic performance. IMF Working Paper.

Louzis, D. P., Vouldis, A. T., \& Metaxas, V. L. (2012). Macroeconomic and bank-specific determinants of non-performing loans in Greece: A comparative study of mortgage, business and consumer loan portfolios. Journal of Banking \& Finance, 36(4), 1012-1027. http://dx.doi:10.1016/j.jbankfin.2011.10.012

Podpiera, J., Weill, L. (2008). Bad luck or bad management? Emerging banking market experience. Journal of Financial Stability, 4, 135-148.

Quagliariello, M. (2007). Banks' riskiness over the business cycle: a panel analysis on Italian intermediaries. Applied Financial Economics, 17(2), 119-138. http://dx. doi.10.1080/09603100500486501

Ruckes, M., (2004). Bank competition and credit standards. The Review of Financial Studies, 17, 1073-1102. http://dx. doi: $10.1093 / \mathrm{rfs} / \mathrm{hhh} 011$

Rajan, R., Dhal, S. C. (2003), Non-performing loans and terms of credit of public sector banks in India: An empirical assessment. Reserve Bank of India Occasional Papers, 24(3), 81-121.

Rinaldi, L., Sanchis-Arellano, A., (2006). Household Debt Sustainability: What Explains Household Non-performing Loans? An Empirical Analysis. ECB Working Paper.

Salas, V., \& Saurina, J. (2002). Credit Risk in Two Institutional Regimes: Spanish Commercial and Savings Banks, Journal of Financial Services Research, 22(3), 203-24. http://dx.doi.10.1023/A:1019781109676

Ozili, P. K. (2015). Credit Smoothing and Determinants of Loan Loss Reserves. Evidence from Europe, US, Asia and Africa. Journal of Business, Economics and Finance, 4(2). (Forthcoming)

\section{(cc) EY}

This work is licensed under a Creative Commons Attribution 3.0 License. 